\title{
Transcription and cell cycle-dependent development of intranuclear bodies and granules in two-cell bovine embryos
}

\author{
P. Hyttel ${ }^{1}$, D. Viuff ${ }^{1,2}$, B. Avery ${ }^{2}$, J. Laurincik ${ }^{3}$ and T. Greve ${ }^{2}$ \\ 'Department of Anatomy and Physiology and ${ }^{2}$ Department for Clinical Studies, Reproduction. The Royal \\ Veterinary and Agricultural University, Bülowsvej 13, DK-1870 Frederiksberg C, Denmark; and \\ ${ }^{3}$ Research Institute of Animal Production, Hlohovska 2, 94992 Nitra, Slovak Republic
}

Bovine two-cell embryos were produced by maturation and fertilization in vitro and isolated at 27,30 or $33 \mathrm{~h}$ after insemination. Embryos were incubated with $\left[{ }^{3} \mathrm{H}\right]$ uridine for $10 \mathrm{~h}$. Other embryos were incubated with $\left[{ }^{3} \mathrm{H}\right]$ uridine for $1 \mathrm{~h}$ starting at $0-3 \mathrm{~h}, 3-6 \mathrm{~h}, 6-9 \mathrm{~h}$ or 9-12 h after cleavage (hpc) to the two-cell stage. Subsequently, all embryos were washed, fixed, dehydrated, embedded in Epon and sectioned for light microscope autoradiography and transmission electron microscopy. Thus, at the time of fixation the embryos incubated in $\left[{ }^{3} \mathrm{H}\right]$ uridine for $1 \mathrm{~h}$ represented the periods $1-4,4-7,7-10$ and $10-13 \mathrm{hpc}$. Among embryos subjected to $\left[{ }^{3} \mathrm{H}\right]$-uridine incubation for $10 \mathrm{~h}$, a majority of those in interphase displayed auto-radiographic labelling over the nuclei, whereas none of the embryos incubated for I h did so. At 1-4 hpc, two-cell embryos presented electron-dense nucleolus precursor bodies and large clusters of electron-dense granules of various sizes in their nuclei. At 4-7 hpc, ring-shaped or horseshoe-shaped bodies of the same electron density as the nucleolus precursor bodies were found in the periphery of the granule clusters. At 7-10 hpc, several incomplete ring-like bodies of the same electron density as the nucleus precursor bodies were found deeply embedded in the granule clusters. The interior of these bodies contained granules lining a central vacuole. At 10-13 hpc, all two-cell embryos were in mitosis. It is concluded that bovine embryos produced in vitro display a certain rate of transcription during the second cell cycle without the presence of a well-defined transcriptional peak, and that this activity is paralleled by cell cycle-dependent interaction of intranuclear bodies and granules.

\section{Introduction}

The regulation of initial embryonic development has been studied in several mammalian species, and it is well established that activation of major portions of the embryonic genome occurs at a species-specific stage of development (Telford et al., 1990; Schultz and Heyner, 1992). In cattle, this process takes place in the eight-cell embryo, that is, during the fourth embryonic cell cycle (Camous et al., 1986). At this developmental stage the first incorporation of $\left[{ }^{3} \mathrm{H}\right]$ uridine into the blastomere nuclei can be detected after incubation for $20 \mathrm{~min}$ with the tracer followed by autoradiography on semi-thin sections. Correspondingly, qualitative changes in bovine embryonic protein synthesis occur from the fourth to the fifth cell cycle (Frei et al., 1989).

The major gene activation seen during the fourth cell cycle in cattle is paralleled by marked ultrastructural changes in the blastomere nucleoli (Camous et al., 1986; King et al., 1988; Kopecny et al., 1989). In general, it has been accepted that nucleoli up to the fourth cell cycle occur in the form of spherical electron-dense nucleolus precursor bodies (NPB), that

Revised manuscript received 19 August 1996. these structures become vacuolized during the fourth cell cycle, and that they develop into fibrillo-granular nucleoli at the end of this cycle. During the fifth cell cycle the fibrillo-granular nucleoli develop fibrillar centres as well. In the bovine embryo, the first signs of rRNA-transcription as detected by ultrastructural autoradiography after $20 \mathrm{~min}$ incubation with $\left[{ }^{3} \mathrm{H}\right]$ uridine coincide with the vacuolization of the nucleolus precursor body (Kopecny et al., 1989).

Other studies demonstrate that although activation of major portions of the bovine genome occurs during the fourth cell cycle, the genome is not completely silent until this stage of development. Thus, in bovine embryos produced in vitro, it is possible to block the synthesis of certain proteins by $\alpha$-amanitin during the third (Barnes and First, 1991) and even the second (Marcucio et al., 1995) cell cycle, indicating that the synthesis is dependent upon transcription of embryonic genes. More directly, recent investigations have shown that some embryonic transcription can be detected during the second cell cycle by the use of long-term $(4-10 \mathrm{~h})$ incubation with $\left[{ }^{3} \mathrm{H}\right]$ uridine and then autoradiography on spread preparations (Plante et al., 1994; Viuff et al., 1996).

The first bovine embryonic cell cycle is of a duration of about $20-24 \mathrm{~h}$, at least in vitro, while the second and third 
cycles last for about $12-13 \mathrm{~h}$ and $13-14 \mathrm{~h}$, respectively. They are rather short in comparison to the fourth cycle, which lasts for about 21-30 h (Barnes and Eyestone, 1990). In this context, it should be kept in mind that the first cycle is atypical, since it succeeds meiosis and initially includes two nuclear compartments in the form of pronuclei. On the basis of this chronological information it has been suggested that the first cell cycle is too specialized and the second and third are too short to allow for transcription (Barnes and Eyestone, 1990). Accordingly, Kimelmann et al. (1987) proposed that in Xenopus embryos, the activation of transcription is triggered by a lengthening of the twelfth cell cycle. These considerations focus on the possible role of cell cycle chronology in relation to embryonic transcription, and a cell cycle-dependent localization of RNA polymerase II in the nuclei coinciding with the appearance of $\alpha$-amanitin sensitive protein synthesis during the second half of the second cell cycle has been demonstrated in bovine embryos (Marcucio et al., 1995).

To date, there is no information available relating possible structural nuclear changes to the initial transcriptional activity during the second cell cycle. Therefore, it was the aim of the present study to investigate (1) the transcriptional activity during the second cell cycle in bovine embryos produced in vitro by the use of incubation with $\left[{ }^{3} \mathrm{H}\right]$ uridine for $10 \mathrm{~h}$, followed by autoradiography on semi-thin sections; and (2) the conceivable cell cycle-dependent ultrastructural changes that may parallel this transcription.

\section{Materials and Methods}

\section{Production of embryos in vitro}

The protocol for embryo production in vitro described by Madison et al. (1992) was used. Briefly, bovine ovaries were collected from an abattoir within $30 \mathrm{~min}$ after slaughter and transported to the laboratory within $2 \mathrm{~h}$ in $0.9 \%(\mathrm{w} / \mathrm{v}) \mathrm{NaCl}$ at $30-33^{\circ} \mathrm{C}$. Oocytes were aspirated from antral follicles with a diameter of $2-8 \mathrm{~mm}$ and subsequently washed three times in $20 \mathrm{mmol}$ Hepes-buffered TCM-199 $\mathrm{I}^{-1}$ (Seromed, Biochrom $K G$, Berlin) supplemented with $10 \%$ oestrus cow serum (ECS), $0.2 \mathrm{mmol}$ sodium pyruvate $\mathrm{I}^{-1}$ (Sigma, Copenhagen),

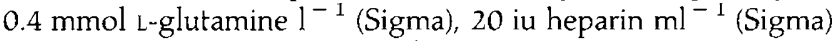
and $50 \mu \mathrm{g}$ gentamycin $\mathrm{ml}^{-1}$ (Sigma). The oocytes were matured for $24 \mathrm{~h}$ in $25 \mathrm{mmol}$ bicarbonate-buffered TCM-199 $\mathrm{I}^{-1}$ supplemented with $10 \%$ ECS, 20 iu Suigonan Vet ${ }^{12} \mathrm{ml}^{-1}$ (Intervet Scandinavia, Copenhagen; eCG:hCG = 2:1), $0.2 \mathrm{mmol}$ sodium pyruvate $\mathrm{l}^{-\mathrm{I}}, 0.4 \mathrm{mmol}$ L-glutamine $\mathrm{I}^{-1}$ and $50 \mu \mathrm{g}$ gentamycin $\mathrm{ml}^{-1}$.

For insemination in vitro, frozen-thawed semen from one bull of proven fertility was used. The oocytes matured in vitro were washed twice and transferred to $25 \mathrm{mmol}$ bicarbonate buffered TALP medium $\mathrm{l}^{-1}$ supplemented with $30 \mathrm{~g}$ heparin $\mathrm{ml}^{-1}$, $20 \mu$ mol D-penicillamine $\mathrm{I}^{-1}$ (Sigma), $10 \mu \mathrm{mol}$ hypotaurine $\mathrm{I}^{-1}$ (Sigma), $6 \mathrm{mg}$ bovine serum albumin $\mathrm{ml}^{-1}$ (Fraction V, Sigma) and co-incubated with spermatozoa originating from a discontinuous Percoll gradient at 55\% and 90\% (Pharmacia, Uppsala) at a final concentration of $2 \times 10^{6} \mathrm{ml}^{-1}$.

At $20 \mathrm{~h}$ after insemination, the ova were freed from unbound spermatozoa and most cumulus cells by repeated passage through a fine bore pipette. They were then co-cultured for various periods in Menezo-B2 medium (INRA, Nouzilly) supplemented with $10 \%$ ECS and a suspension of bovine oviduct cells $(1: 100 \mathrm{v} / \mathrm{v}$, in vitro culture medium). The bovine oviduct cells were prepared from oviducts collected from the abattoir at the same time as the ovaries. The epithelial sheets $(1: 50 \mathrm{v} / \mathrm{v})$ were cultured in tissue culture flasks (Nunc, Roskilde) in bicarbonate-buffered TCM-199 supplemented with $10 \% \mathrm{ECS}, 1 \mathrm{mmol}$ L-glutamine $\mathrm{I}^{-1}, 50 \mu \mathrm{g}$ gentamycin $\mathrm{ml}^{-1}$, $2.5 \mu \mathrm{g}$ amphotericin $\mathrm{B} \mathrm{m}{ }^{-1}$ (Gibco, Copenhagen) until co-culture with the ova $48 \mathrm{~h}$ later. All incubations were performed at $39^{\circ} \mathrm{C}$ in $5 \% \mathrm{CO}_{2}$ in humidified air. In vitro maturation and insemination were carried out in four-well multidishes with approximately 50 ova in $0.5 \mathrm{ml}$ medium per well. The in vitro culture was carried out in $100 \mu \mathrm{l}$ droplets (approximately 20 ova per droplet) under oil (Uvasol-Merck, Copenhagen).

\section{$l^{3}$ H]uridine incubation}

At either 27 or $32 \mathrm{~h}$ after insemination (hpi), two-cell embryos were removed from the in vitro culture and transferred to $100 \mu \mathrm{l}$ droplets under oil containing $25 \mathrm{~mol}$ bicarbonatebuffered TCM-199 $\mathrm{I}^{-1}$ supplemented with $1 \%$ BSA (w/v) (Sigma) and $200 \mu \mathrm{Ci} ~^{3} \mathrm{H}$ ]uridine $\mathrm{ml}^{-1}$ (Amersham PLC, Little Chalfont) for $10 \mathrm{~h}$ (long term) at $39^{\circ} \mathrm{C}$ in $5 \% \mathrm{CO}_{2}$ in humidified air. Subsequently, the embryos were washed twice in cold PBS supplemented with 10\% fetal calf serum (PBSS), held for $30 \mathrm{~min}$ at $4^{\circ} \mathrm{C}$ in PBSS supplemented with $5 \mathrm{mg}$ unlabelled uridine $\mathrm{ml}^{-1}$, washed once more in PBSS and fixed $(n=8$, see later).

After removal of all two-cell embryos at $27 \mathrm{hpi}$, the remaining ova were cultured until $30 \mathrm{hpi}$, at which time all newly developed two-cell embryos were allocated to one of four groups. The remaining one-cell ova were cultured until $33 \mathrm{hpi}$, at which time all newly developed two-cell embryos again were allocated to one of four groups in parallel to those above. At each time point, Group 1 was cultured in the presence of $\left[{ }^{3} \mathrm{H}\right]$ uridine for $1 \mathrm{~h}$ (pulse) as described for the $10 \mathrm{~h}$ incubations and washed and fixed, that is, fixed at $1-4 \mathrm{~h}$ after cleavage (hpc) to the two-cell stage $(n=10)$. Groups 2,3 and 4 were cultured in the absence of $\left[{ }^{3} \mathrm{H}\right]$ uridine for 3,6 and $9 \mathrm{~h}$, respectively, before a final $1 \mathrm{~h}$ incubation in the presence of $\left[{ }^{3} \mathrm{H}\right]$ uridine as described above followed by washing and fixation. Thus, Groups 2, 3 and 4 were fixed at $4-7(n=10)$, $7-10(n=8)$ and $10-13(n=5)$ hpc.

\section{Processing for light microscope autoradiography and transmission electron microscopy}

The embryos were fixed in $3 \%(\mathrm{v} / \mathrm{v})$ glutaraldehyde in 0.1 mol phosphate buffer $\mathrm{l}^{-1}$ for $\mathrm{I} \mathrm{h}$ at $4^{\circ} \mathrm{C}$, washed in $0.1 \mathrm{~mol}$ phosphate buffer $\mathrm{l}^{-1}$, embedded in $4 \%(\mathrm{w} / \mathrm{v})$ agar (Hyttel and Madsen, 1987) and, after a second wash in 0.1 mol phosphate buffer $1^{-1}$, they were post-fixed in $1 \%(\mathrm{w} / \mathrm{v}) \mathrm{OsO}_{4}$ in $0.1 \mathrm{~mol}$ phosphate buffer $\mathrm{I}^{-1}$ for $1 \mathrm{~h}$ at $4^{\circ} \mathrm{C}$. Subsequently, they were dehydrated in a graded series of ethanol and embedded in Epon after intermediate steps in propylene oxide. Finally, each embryo $(n=43)$ was serially sectioned into semi-thin sections $(2 \mu \mathrm{m})$ and every second section was stained with $1 \%(\mathrm{w} / \mathrm{v})$ 
Table 1. Developmental stage and autoradiographic labelling of two-cell bovine embryos after $\left[{ }^{3} \mathrm{H}\right] \mathrm{uridine}$ incubation

\begin{tabular}{|c|c|c|c|c|c|}
\hline \multirow{2}{*}{$\begin{array}{l}\text { Time of } \\
\text { fixation } \\
\left(\text { hpc) }{ }^{a}\right.\end{array}$} & \multirow{2}{*}{$\begin{array}{c}\text { Number of } \\
\text { embryos }\end{array}$} & \multirow{2}{*}{$\begin{array}{l}{\left[{ }^{3} \text { H]uridine }\right.} \\
\text { incubation } \\
\text { (h) }\end{array}$} & \multicolumn{3}{|c|}{$\begin{array}{c}\text { Number of embryos at developmental } \\
\text { stage after }\left[{ }^{3} \mathrm{H}\right] \text { uridine incubation } \\
\text { (labelled number) }\end{array}$} \\
\hline & & & Two-cell & Three-cell & Four-cell \\
\hline - & 8 & 10 & $2(1)^{b}$ & & $6(5)$ \\
\hline $1-4$ & 10 & 1 & $10(0)$ & & \\
\hline $4-7$ & 10 & 1. & $7(0)$ & $1(0)$ & $2(0)$ \\
\hline $7-10$ & 8 & 1 & $6(0)^{c}$ & & $2(0)$ \\
\hline $10-13$ & 5 & 1 & $2(0)^{b}$ & & $3(0)$ \\
\hline
\end{tabular}

${ }^{2}$ Hours after cleavage to the two-cell stage.

'One two-cell embryo displayed two metaphases.

cone two-cell embryo displayed one prophase and one metaphase.

(a)

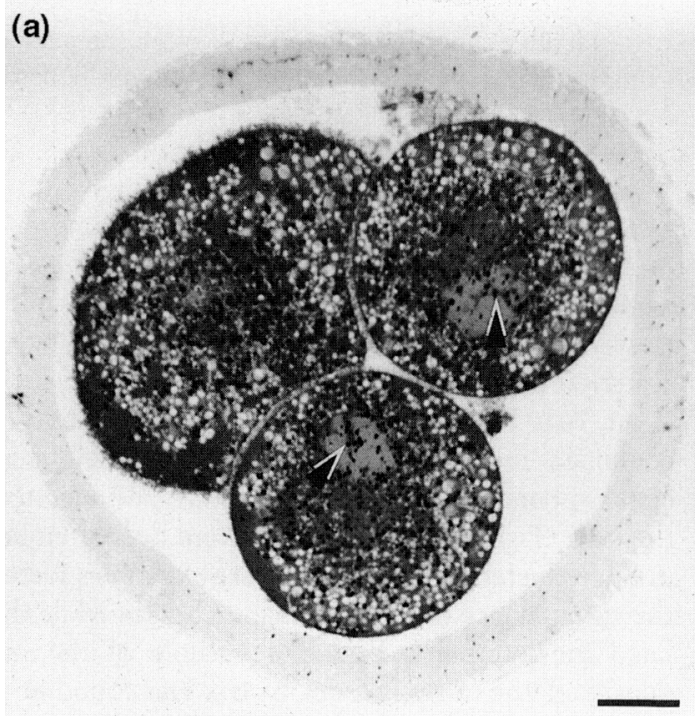

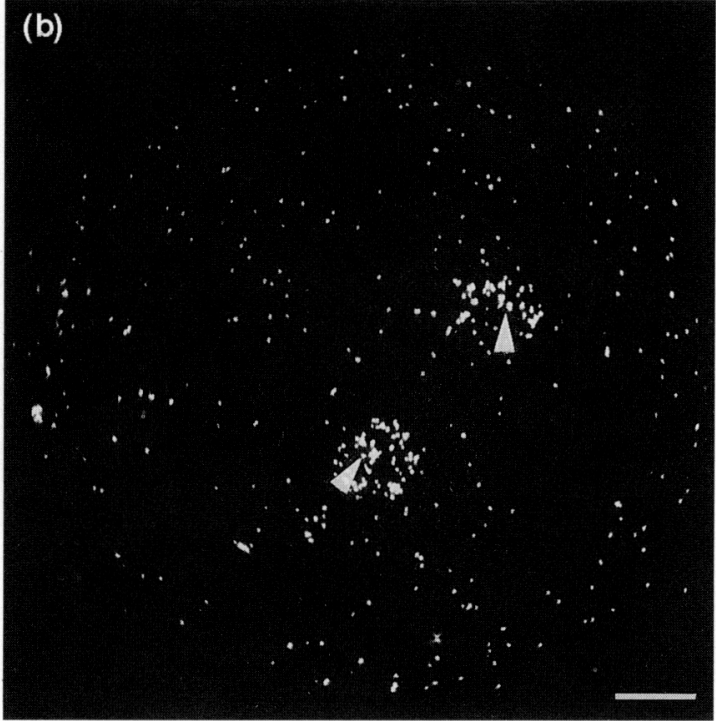

Fig. 1. Bright field (a) and epipolarized (b) photo-micrographs of a four-cell bovine embryo incubated at the two-cell stage with $\left[{ }^{3} \mathrm{H}\right]$ uridine for $10 \mathrm{~h}$. Note the autoradiographic labelling over the nuclei, which is associated with strands of heterochromatin (arrowheads). Scale bars represent $20 \mu \mathrm{m}$.

basic toluidine blue and examined by bright field light microscopy.

Adjacent unstained sections, possibly including nucleoluslike structures, were selected for autoradiography. They were dipped in Ilford K2 photographic emulsion (Ilford, Copenhagen) diluted with one part of water, dried for $2 \mathrm{~h}$ at room temperature and stored in sealed boxes wrapped in aluminium foil for exposure at $4^{\circ} \mathrm{C}$ for 4 weeks. Subsequently, the autoradiograms were developed in D-19 (Kodak, Paris) for $5 \mathrm{~min}$, stained with $1 \%(\mathrm{w} / \mathrm{v})$ basic toluidine blue, and evaluated by bright field and epipolarized light microscopy.

Other sections presenting nucleolus-like structures in all embryos incubated with $\left[{ }^{3} \mathrm{H}\right]$ uridine for $1 \mathrm{~h}$ were selected, re-embedded according to Hyttel and Madsen (1987), ultrathin sections for transmission electron microscopy (TEM) were prepared and contrasted with uranyle acetate and lead citrate, and examined on a JEOL 1200EX transmission electron microscope at $60 \mathrm{kV}$.

\section{Results}

\section{Cleavage and autoradiographic labelling}

The developmental stages and autoradiographic labelling of the embryos following long term or pulse incubation with ${ }^{3} \mathrm{H}$-uridine are shown (Table 1). The majority of the embryos incubated with $\left[{ }^{3} \mathrm{H} \mid\right.$ uridine for $10 \mathrm{~h}$ exhibited labelling over the nuclei (Fig. 1). Only a low degree of background labelling was detected over the cytoplasm and the zona pellucida. The grains were typically located towards the periphery of the nuclei and were associated with strands of heterochromatin. No spatial relationship was noted between the labelling and any of the 
(a)

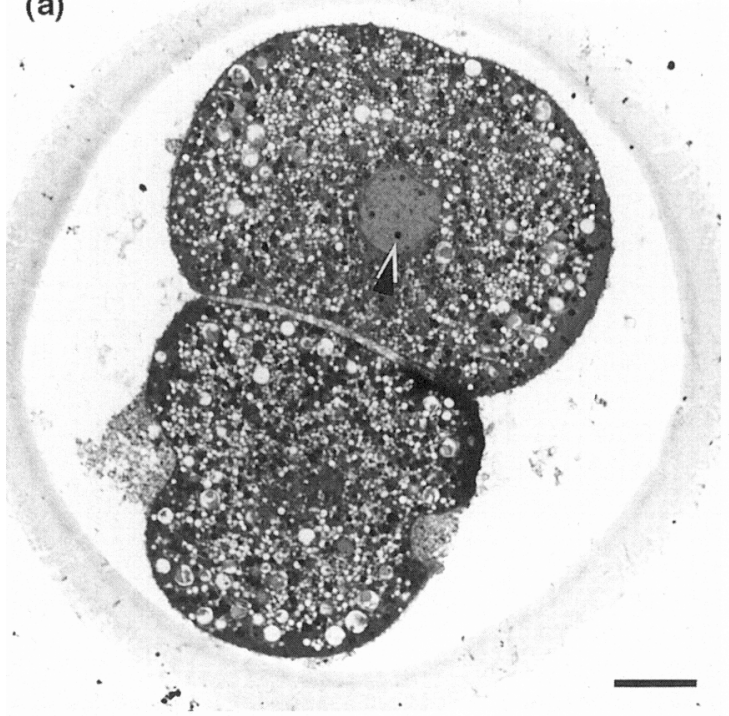

(b)

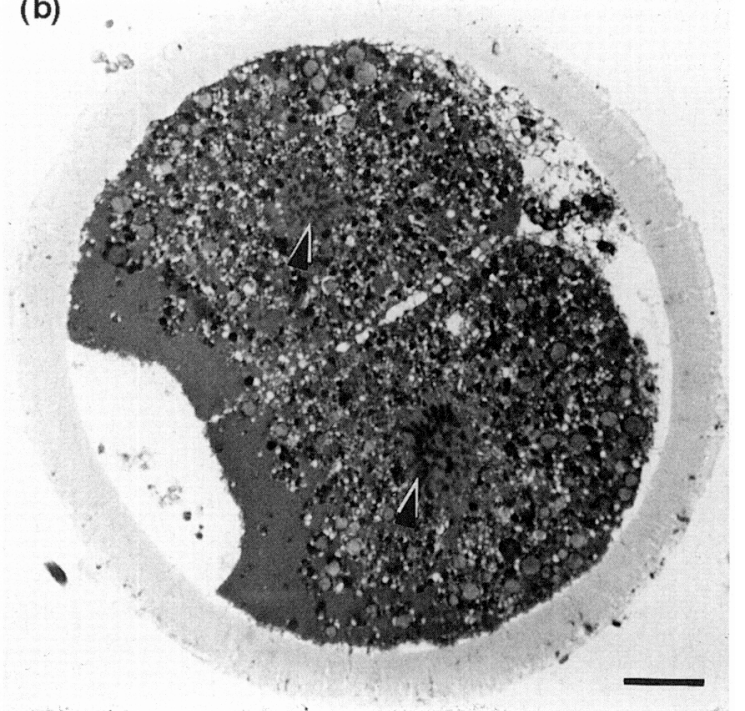

Fig. 2. Bright field micrographs of two-cell bovine embryos fixed $1-4 \mathrm{~h}$ after cleavage (hpc) to the two-cell stage (a) and 10-13 hpc (b). Note the nucleolus precursor body (a, arrowhead) and the metaphase in each cell (b, arrowheads). Scale bars represent $20 \mu \mathrm{m}$.

nuclear bodies described in this study. The labelling of the two-cell embryo was less distinct than that of four-cell embryos. None of the embryos submitted to $1 \mathrm{~h}$ incubation with $\left[{ }^{3} \mathrm{H}\right]$ uridine displayed labelling. With increasing $\mathrm{hpc}$, an increasing number of embryos showed metaphases (Fig. 2) or cleavage.

\section{Ultrastructure}

At 1-4 hpc, the most prominent structural components of the blastomere nuclei were NPB consisting of an electron-dense mass of densely packed fibrils (Fig. 3a). Often, some portions of the NPBs appeared more electron-dense than others. Typically, the outline of the NPBs appeared granulated with chromatinlike material attached to it. On some occasions clusters of granules associated with chromatin-like material were observed at other locations in the same nuclei. The granule clusters consisted of two spatially separated populations of large granules and small granules (Fig. 3b). In addition to these nuclear structures, scattered portions of heterochromatin were observed. In two of the ten embryos, however, the nuclei were dominated by abundant heterochromatic strands and no NPB were observed.

The perinuclear cytoplasm was characterized by an abundance of Golgi complexes (Fig. 3c), mitochondria (Fig. 3a) and annulate lamellae (Figs. 3a, c), of which the latter presented more or less pore-like constrictions. The annulate lamellae were typically associated with large numbers of free ribosomes and polyribosomes (Figs. 3a, c).

At $4-7 \mathrm{hpc}$, the two-cell embryos presented NPB of the same morphological appearance as described above. However, ring-shaped (Fig. 4a) or horseshoe-shaped (Fig. 4b) bodies apparently of the same composition and electron-density as the NPB were also observed in the periphery of the granule clusters, which still consisted of two separate populations of granules. Small granules occupied the centre of the ring-shaped or horseshoe-shaped bodies. The granule clusters were often associated with chromatin-like material. Both NPB and granule clusters were observed in the same nuclei, again, together with scattered portions of heterochromatin.

At 7-10 hpc, the granule clusters of the two-cell embryos contained incomplete slightly flattened ring-shaped bodies, again apparently of the same texture and electron-density as the NPB (Fig. 4c). These bodies were deeply embedded in the granule clusters. Typically, the large granules were arranged at the external face of the ring-shaped bodies while the small ones lined the internal face, and a vacuole of the same electron density as the nucleoplasmic matrix was found at the centre of the structure. Again, both NPB and granule clusters could be observed in the same nuclei together with scattered portions of heterochromatin.

In the perinuclear region, abundant annulate lamellae were associated with free ribosomes and polyribosomes (Fig. 4d) and an abundance of Golgi complexes was observed. These complexes were often associated with pores in the nuclear envelope.

At $10-13 \mathrm{hpc}$, no additional structural findings were recorded.

In the four-cell embryos encountered at 4-7,7-10, and 10-13 hpc, ring-shaped bodies apparently of the same composition and electron density as the NPB but without granule association were observed. On some occasions, these bodies presented both a central and at least one additional smaller eccentric vacuole (Fig. 4e). Both central and eccentric vacuoles contained chromatin-like material.

\section{Discussion}

The present paper describes the appearance and cell cycledependent development of intranuclear bodies and granules 

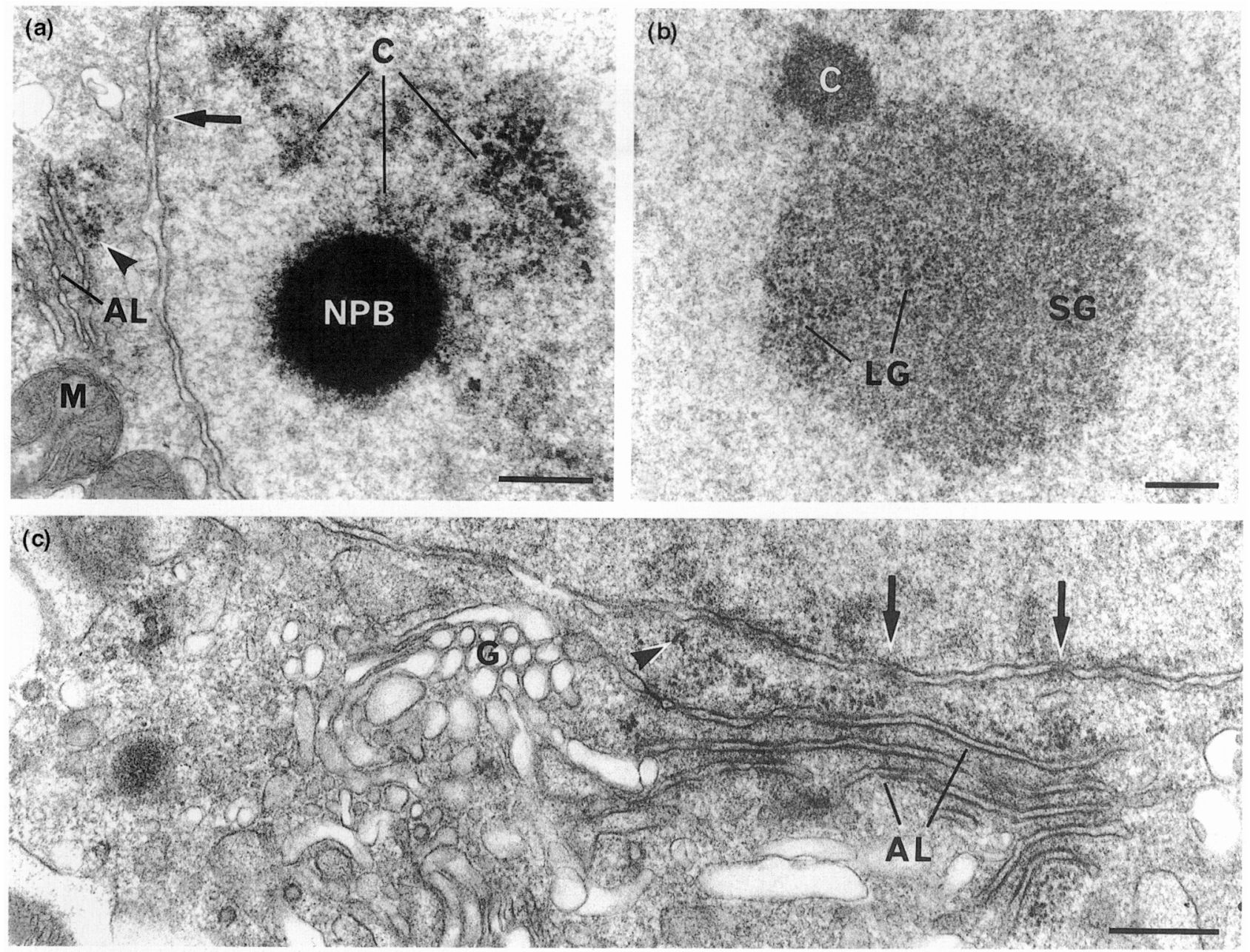

Fig. 3. Details from two-cell bovine embryos fixed $\mathrm{I}-4 \mathrm{~h}$ after cleavage to the two-cell stage. (a) Shows a nucleolus precursor body (NPB) contained in the nucleus delineated by the nuclear envelope displaying a single pore (arrow). Note that the NPB is associated with chromatin-like material along the full circumference, clumps of chromatin-like material (C) are also seen in its vicinity. In the cytoplasm, mitochondria (M) and annulate lamellae (AL) associated with polyribosomes (arrowhead) are seen. (b) Shows a granule cluster associated with chromatin-like material (C). Note that the cluster consists of small (SG) and fewer large (LG) granules that occupy different domains in the cluster. (c) Shows a Golgi complex (G) and annulate lamellae (AL) associated with ribosomes and polyribosomes (arrowhead). Note the intimate association with these structures and the nuclear envelope presenting a couple of pores (arrows). Scale bars represent $0.4 \mu \mathrm{m}$.

during the second cell cycle in bovine embryos produced in vilro. Furthermore, it documents embryonic transcription at this early stage of development by autoradiography on semithin sections at least after $10 \mathrm{~h}$ incubation with $\left[{ }^{3} \mathrm{H}\right]$ uridine. Alexandre (1977) demonstrated a biochemical pathway resulting in incubation of $\left[{ }^{3} \mathrm{H}\right]$ uridine into DNA during 4-6h incubation of preimplantation mouse embryos. However, based upon the control experiments set up in a parallel study using $10 \mathrm{~h}\left[{ }^{3} \mathrm{H}\right]$ uridine incorporation and spread preparation of large numbers of two- and four-cell embryos produced in vitro, we are confident that the autoradiographic labelling does signal RNA synthesis and not other mechanisms of binding or incorporation (Viuff et al., 1996). Thus, in the cited experiment it was possible to (1) decrease the rate of incorporation competitively by addition of unlabelled uridine, (2) avoid labelling by RNase treatment of the slides before autoradiographic processing, and (3) record labelling in total RNA extracted from the embryos.
None of the embryos submitted to I h $\left[^{3} \mathrm{H}\right]$ uridine incubation displayed autoradiographic labelling. This result points at the presence of a low rate of transcription during large portions of the cell cycle rather than the occurrence of a well-defined transcriptional peak. This result is in accordance with previous reports using $3 \mathrm{~h}\left[^{3} \mathrm{H}\right]$ uridine incubation periods over the second cell cycle followed by autoradiography on spreads (Viuff et al., 1996).

During the second cell cycle, the present study revealed two different intranuclear components in addition to heterochromatic formations: the NPB and the granule clusters, which were made up of two separate populations of granules differing in size. The NPB are considered as precursors for the fibrillogranular nucleoli established during the fourth embryonic cell cycle in cattle (King et al., 1988; Kopecny et al., 1989). In human preimplantation embryos, these bodies are thought to be composed of fibrillar nucleolar matrix elements arranged in fibrils, not to contain DNA, and to lack RNA synthetic activity 

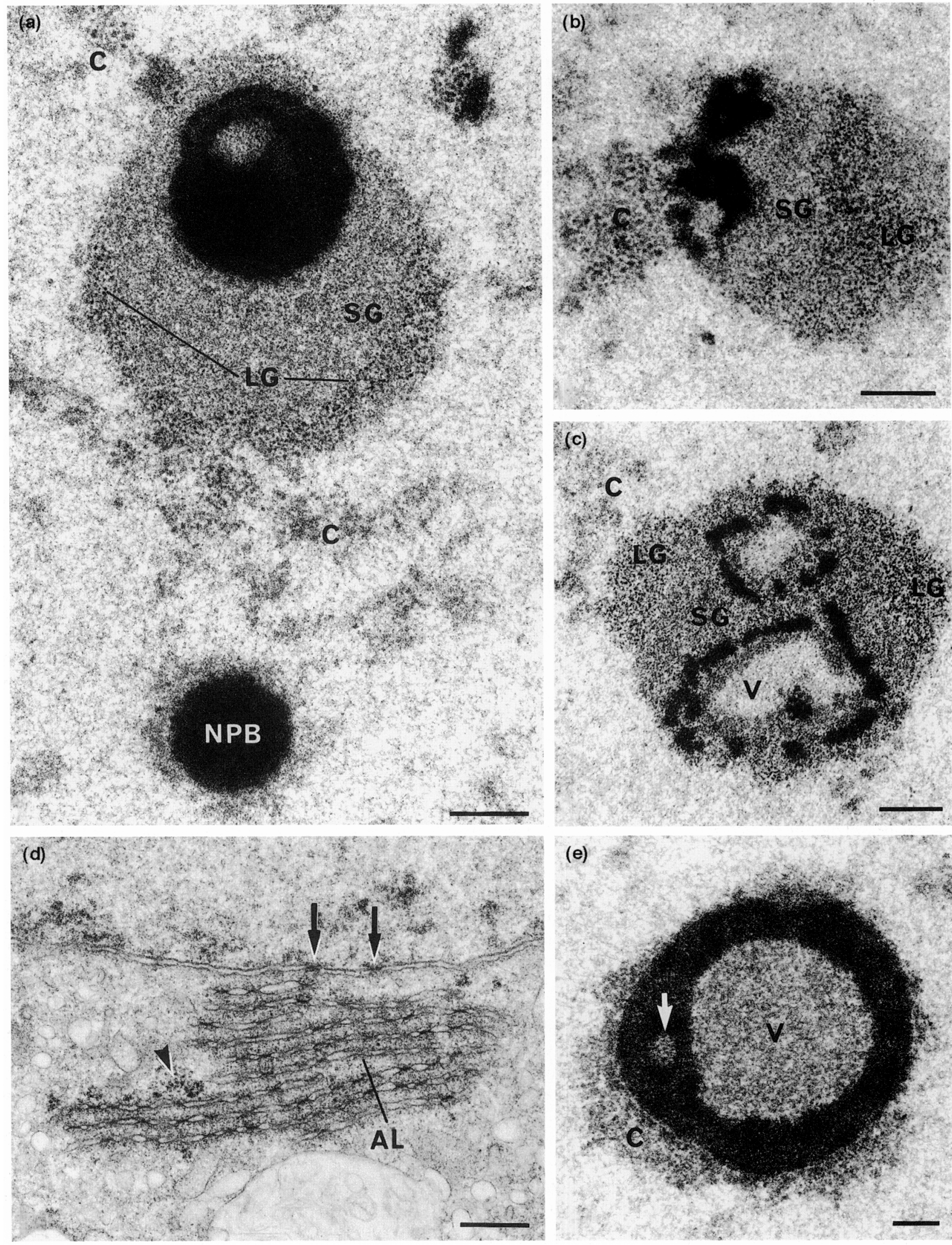
(Tesarik ef al., 1987). At least in parthenogenetically activated mouse oocytes, the NPB contain RNA of maternal origin (Kopecny et al., 1995). The granule clusters described in the present report resemble the clusters of interchromatin granules reported in two-cell mouse embryos (Fakan and Odartchenko, 1980). In mice, these clusters contain granules of various sizes $(15-20 \mathrm{~mm})$ intermingled between each other, whereas the present study demonstrates that large and small granules occupy different domains within a cluster in cattle. In both mouse (Fakan and Odartchenko, 1980) and cattle (Kopecny et al., 1991) embryos, the interchromatin granules contain small nuclear ribonuclear proteins, detectable by immunocytochemistry, that are complexes of small nuclear RNA associated with specific proteins, and are engaged in the splicing of pre-mRNA (for review, see Steitz et al., 1988). The present study demonstrates a striking cell cycle-dependent interaction between the NPB and the interchromatin granule clusters during the second embryonic cell cycle in cattle. Thus, early during the cell cycle these components were observed on separate locations in the nucleus, whereas later in the cycle NPB-like material was found in the granule clusters.

The cell cycle-dependent interaction between NPB and interchromatin granule clusters is chronologically related to a cell cycle-dependent relocation of RNA polymerase II from the cytoplasm to the nuclei and a coinciding appearance of $\alpha$-amanitin-sensitive protein synthesis during the second half of the second cell cycle in bovine embryos produced in vitro (Marcucio et al., 1995). Thus, the restructuring of the interchromatin granule clusters may be related to their presentation of RNA polymerase II allowing for mRNA transcription. There is, however, no information available of the location or activity of RNA polymerase I and III. Neither has the nature of the transcripts produced been addressed. In mice, the activation of the embryonic genome is divided into two phases (Flach $e t$ al., 1982). The first and minor activation occurring during the first cell cycle is thought to depend upon post-translational modifications of maternally derived proteins that may regulate the onset of RNA polymerase activity (Schultz, 1993). When the second and major activation occurs during the second cell cycle, unknown regulatory events that govern the selectiveness of RNA polymerase II appear to operate. At least in mice, the HSP 70.1 gene has, as the first gene, been expressed during the minor gene activation from the $G 2$ phase of the first embryonic cell cycle up to the S-phase of the second cycle, where the major gene activation occurs and during which the HSP 70.1 gene is not expressed (Christians et al., 1995). If it is assumed that the transcriptional activation during the fourth embryonic cell cycle in cattle is equivalent to the major activation during the second cell cycle in mice, the transcriptional activity demonstrated in bovine two-cell embryos must represent part of the minor activation seen in mouse zygotes. In this context, it would be relevant to explore the possible expression of candidates of the multigenic hsp 70 family that includes the HSP 70.1 gene as a member.

The embryos fixed during the third cell cycle in the present experiment displayed both primary and secondary vacuolization of the NPB, a feature that was considered to take place during the fourth cell cycle (King et al., 1988; Kopecny et al., 1989) and which is associated with the onset of presumptive rRNA transcription (Kopecny et al., 1989). A chronological investigation of the third bovine embryonic cell cycle is still lacking, but such experimentation is hampered by the asynchrony established between blastomeres at this stage of development (Viuff et al., 1996).

It should be emphasized that the present data are generated on the basis of embryos produced in vitro. Pavlok et al. (1993) concluded that embryos produced in vitro from oocytes aspirated from follicles $>2 \mathrm{~mm}$ in diameter with respect to embryonic gene expression, as determined by $\left[{ }^{3} \mathrm{H}\right]$ uridine incorporation at the eight-cell stage and accompanying nucleolar activation, are comparable to embryos produced in vivo. This is in contrast to embryos derived from oocytes collected from follicles $<2 \mathrm{~mm}$, where lack of gene activation was a common phenomenon.

In conclusion, bovine embryos produced in vitro display a certain rate of transcription during the second cell cycle without the presence of a well-defined transcriptional peak, and this activity is paralleled by cell cycle-dependent appearance and complex interaction of intranuclear electron-dense bodies and granules.

The authors thank $\mathbf{j}$. Nielsen and B. Poulsen for skilful sectioning and production of photographs and R. H. F. Hunter, T. Fair and $P$. Lonergan for valuable suggestions for the text. The work was supported by the Danish Agricultural and Veterinary Research Council.

\section{References}

Alexandre H (1977) Nucleic acid synthesis in preimplantation mouse embryos - autoradiographic evidence of uridine and deoxyuridine utilization in DNA synthesis Roux's Archives of Developmental Biology 181 193-202

Fig. 4. Details from two-cell bovine embryos fixed (a, b) 4-7 h after cleavage (hpc) to the two-cell stage (c, d) 7-10 hpc, and (e) from a four-cell embryo fixed 10-13 hpc. (a) Shows a granule cluster containing a ring-shaped body of apparently the same composition as the nucleolus precursor body (NPB) in the same nucleus. Note that small (SG) and large (LG) granules occupy different domains of the granule cluster, that the centre of the ring-shaped body contains small granules, and that the NPB is associated with chromatin-like material (C). (b) Shows a granule cluster containing two peripherally located horseshoe-shaped bodies of apparently the same composition as the nucleolus precursor bodies. Note that small (SG) and large (LG) granules occupy different domains of the granule cluster, which is associated with chromatin-like material (C). (c) Shows a granule cluster with deeply embedded incomplete ring-shaped bodies of apparently the same composition as the nucleolus precursor bodies. Note that the small (SG) and large (LG) granules occupy different domains of the granule cluster, which is associated with chromatin-like material (C), that preferentially small granules are found at the inside of the ring-shaped body, and that the centre of the body consists of a vacuole (V) of the same electron-density as the nucleoplasmic matrix. (d) Shows well-developed annulate lamellae (AL) with associated polyribosomes (arrowhead). Note that the nuclear envelope displays a couple of pores (arrows) facing the annulate lamellae. (e) Shows a nucleolus precursor body with a primary central vacuole $(V)$ and a peripheral secondary vacuole (arrow). Note that the NPB is associated with chromatin-like material (C) that is also contained within the vacuoles. Scale bars represent $0.4 \mu \mathrm{m}(\mathrm{a}-\mathrm{d})$ and $0.2 \mu \mathrm{m}(\mathrm{e})$. 
Barnes FL and Eyestone WH (1990) Early cleavage and the maternal zygotic transition in bovine embryos Theriogenology 33 141-152

Barnes FL and First NL (1991) Embryonic transcription in in vitro cultured bovine embryos Molecular Reproduction and Development 29 117-123

Camous S, Kopecny V and Fléchon J-E (1986) Autoradiographic detection of the earliest stage of $\left[{ }^{3} \mathrm{H}\right]$ uridine incorporation into the cow embryo Biology of the Cell 58 195-200

Christians E, Campion E, Thompson EM and Renard J-P (1995) Expression of HSP 70.1 gene, a landmark of early zygotic activity in the mouse embryo, is restricted to the first burst of transcription Development 121 113-122

Fakan S and Odartchenko N (1980) Ultrastructural organization of the cell nucleus in early mouse embryos Biologie Cellulaire 37 211-218

Flach G, Johnson MH, Braude PR, Taylor RAS and Bolton VS (1982) The transition from maternal to embryonic control in the 2-cell mouse embryo EMBO joumal 6 681-686

Frei RE, Schultz GA and Church RB (1989) Qualitative and quantitative changes in protein synthesis occur at the 8-16-cell stage of embryogenesis in the cow Journal of Reproduction and Fertility $86637-641$

Hyttel P and Madsen I (1987) Rapid method to prepare mammalian oocytes and embryos for transmission electron microscopy Acta Anatomica 129 I2-14

Kimelman, D, Kirschner M and Scherson T (1987) The events of the midblastula transition in Xenopus are regulated by changes in the cell cycle Cell $\mathbf{4 8}$ 399-407

King WA, Niear A, Chartrain I, Betteridge KJ and Guay P (1988) Nucleolus organizer regions and nucleoli in preattachment bovine embryos Journal of Reproduction and Ferfility 82 87-95

Kopecny V, Flechon JE, Camous S and Fulka J, Jr (1989) Nucleologenesis and the onset of transcription in the eight-cell bovine embryo: fine-structural autoradiographic study Molecular Reproduction and Development 1 79-90

Kopecny V, Fakan S, Pavlok A, Pivko J, Grafenau P, Biggiogera M, Leser G and Martin TE (1991) Immunoelectron microscopic localization of small nuclear ribonucleoproteins during bovine early embryogenesis Molecular Reproduction and Development 29 209-219
Kopecny V, Landa V and Pavlok A (1995) Localization of nucleic acids in the nucleoli of oocytes and early embryos of mouse and hamster: an autoradiographic study Molecular Reproduction and Development 41 449-458

Madison V, Avery B and Greve T (1992) Selection of immature bovine oocytes for developmental potential in vitro. Animal Reproduction Science 27 1-11

Marcucio RS, Hopwood RM, Ignotz GG and Currie WB (1995) Translation of zygotically-derived mRNA in a cell cycle specific manner in 2-cell cattle embryos Journal of Reproduction and Fertility Abstract Series 15 Abstract 46

Pavlok A, Kopecny V, Lucas-Hahn A and Niemann H (1993) Transcriptional activity and nuclear ultrastructure of 8 -cell bovine embryos developed by in vitro maturation and fertilization of oocytes from different growth categories of antral follicles Molecular Reproduction and Development 35 233-243

Plante L, Plante C, Shepherd DL and King WA (1994) Cleavage and ${ }^{3} \mathrm{H}$-uridine incorporation in bovine embryos of high in vitro developmental potential Molecular Reproduction and Development 39 375-383

Schultz RM (1993) Regulation of zygotic gene activation in the mouse BioEssays 15 53I-538

Schultz DA and Heyner S (1992) Gene expression in pre-implantation mammalian embryos Mutation Research 296 17-31

Steitz JA, Black DL, Gerke V, Parker KA, Kramer A, Frendewey D and Keller W (1988) Functions of the abundant U-snRNPs. In Structure and Function of Major and Minor Small Nuclear Ribonucleoprotein Particles pp 115-154 Ed. ML Birnstiel. Springer-Verlag, Berlin

Telford NA, Watson AJ and Schultz GA (1990) Transition from maternal to embryonic control in early mammalian development: a comparison of several species Molecular Reproduction and Development 26 90-100

Tesarik J, Kopecny V, Plachot M and Mandelbaum J (1987) High-resolution autoradiographic localization of DNA-containing sites and RNA synthesis in developing nucleoli of human preimplantation embryos: a new concept of embryonic nucleologenesis Development 101 777-791

Viuff D, Avery B, Greve T, King WA and Hyttel P (1996) Transcriptional activity in in vitro produced bovine 2- and 4-cell embryos Molecular Reproduction and Development 43 171-179 